\title{
Pengaruh Profitabilitas Terhadap Agresivitas Pajak Dengan Capital Intensity Sebagai Variabel Moderasi
}

Tax aggressiveness,

Profitability and

Capital Intensity

\author{
Muhamad Apep Mustofa ${ }^{1}$ Maryam Amini ${ }^{2} \&$ Syahril Djaddang ${ }^{3}$ \\ ${ }^{123^{2}}$ Sekolah Tinggi Ilmu Ekonomi Hidayatullah, Depok, Indonesia \\ Email : maryam.amini@stiehidayatullah.ac.id
}

\begin{abstract}
This study aims to examine the effect of profitability on tax aggressiveness and the effect of profitability on tax aggressiveness with capital intensity as a moderating variable. The population used in this study is coal mining industry companies that have been listed on the Indonesia Stock Exchange in 2014-2018. Researchers used purposive sampling method with a total sample of 40 samples from 17 companies that have been selected. The results show that intensity capital can moderate the effect of profitability on tax aggressiveness. And also profitability has an effect on tax aggressiveness.
\end{abstract}

Keywords: Profitability, Capital Intensity, and Tax Aggressiveness

\begin{abstract}
ABSTRAK
Penelitian ini bertujuan untuk menguji pengaruh profitabilitas terhadap agresivitas pajak dan pengaruh profitabilitas terhadap agresivitas pajak dengan capital intensity sebagai variabel moderasi. Populasi yang digunakan dalam penelitian ini adalah perusahaan industri pertambangan batu bara yang telah terdaftar di Bursa Efek Indonesia tahun 20142018. Peneliti menggunakan metode purposive sampling dengan total sampel 40 sampel dari 17 perusahaan yang telah terpilih. Hasil penelitian menujukkan bahwa capital intensity dapat memoderasi pengaruh profitabilitas terhadap agresivitas pajak. Dan juga profitabilitas berpengaruh terhadap agresivitas pajak.
\end{abstract}

Kata kunci: Profitabilitas, Capital Intensity, dan Agresivitas Pajak

\section{PENDAHULUAN}

Pajak merupakan kontribusi/sumbangan yang setiap wajib pajak baik wajib pajak orang pribadi maupun wajib pajak badan wajib menyetorkannya kepada negara. Adapun menurut UU KUP pajak adalah kontribusi wajib kepada negara yang terutang oleh pribadi atau badan yang bersifat memaksa. Pendapatan negara atas pajak ialah sumber pendanaan terbesar yang diharapkan pemerintah dalam membangun negeri guna kemakmuran bangsa. Dari pajak tersebut pemerintah dapat menjalankan programnya dengan tujuan meningkatkan perekonomian melalui infrastruktur pembangunan, aset publik dan fasilitas umum lainnya. Hal ini dapat mengakibatkan turunnya pendapatan pajak negara sehingga berdampak pada target pajak yang tidak tercapai. Seperti yang diberitakan oleh kabar harian online cnbcindonesia.com dimana penerimaan pajak tahun 2018 sebesar Rp 1.315,9 triliun kembali tak capai target APBN 2018 sebesar Rp 1.424. Yang mana di tahun 2017 penerimaan pajak pun belum mencapai targetnya yaitu hanya tercapai 89,4\% dari target sebesar Rp 1.283,6 triliun. Kejadian ini mejadi salah satu akibat dari tindakan agresivitas pajak yang dilakukan terutama oleh perusahaan.

Dalam katadata.co.id disebutkan, dibalik besarnya nilai ekonomi yang dihasilkan industri pertambangan batu bara terdapat kontribusi pajak yang sangat minim. Ditambah data dari Kementerian Keuangan yang menunjukkan tax ratio dari kontribusi industri
Submitted: MARET 2021

Accepted: APRIL 2021

\section{JIAKES}

$$
\begin{array}{r}
\text { Jurnal Ilmiah Akuntansi } \\
\text { Kesatuan } \\
\text { Vol. } 9 \text { No. } 1,2021 \\
\text { pg. 173-178 } \\
\text { IBI Kesatuan } \\
\text { ISSN 2337-7852 } \\
\text { E-ISSN } 2721-3048
\end{array}
$$


Tax aggressiveness, Profitability and Capital Intensity

\section{4}

pertambangan batu bara pada 2016 hanya 3,9\% dari target tax ratio 10,4\%. Hal tersebut menunjukkan penerimaan pajak dari sektor pertambangan batu bara masih jauh dari potensi yang sesungguhnya. Data tersebut sejalan dengan data dari penulis terkait tingkat agresivitas pajak untuk industri pertambangan sektor batu bara, seperti grafik dibawah ini.

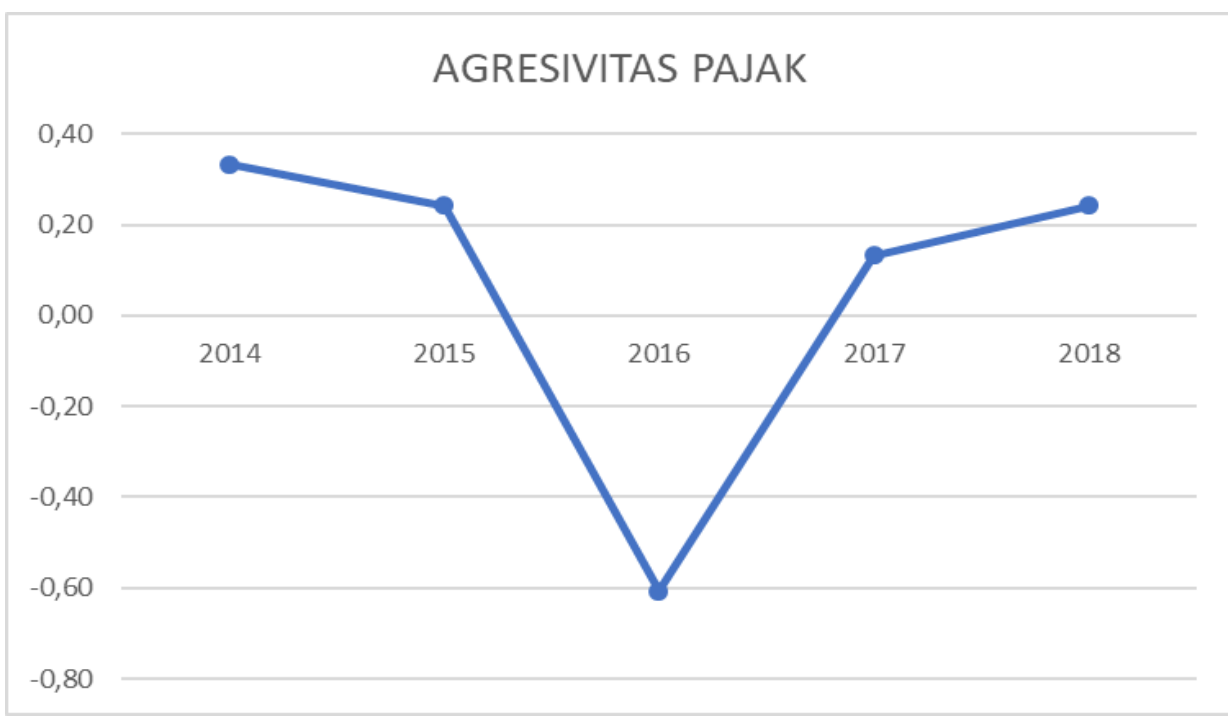

Gambar 1. Agresivitas Pajak

Sumber: Hasil Pengolahan Data, 2019

Dari data di atas terlihat bahwa pada tahun 2017 dan tahun 2018 terdapat kenaikan tingkat agresivitas pajak. Artinya pada tahun tersebut terdapat penghindaran pajak yang meningkat pada perusahaan pertambangan batu bara sebesar 0,13 di tahun 2017 dan meningkat menjadi 0,24 pada tahun 2018. Maka terlihat jelas bahwa tindakan agresivitas perusahaan dapat merugikan negara, sebab mengurangi pendapatan negara atas pajak yang diperuntukkan untuk kemakmuran bangsa. Sayangnya agresivitas pajak ini dinilai positif oleh perusahaan, karena perusahaan dapat memperoleh laba yang lebih besar atas kemampuannya menghindari kewajiban perpajakan.

Beberapa faktor yang mempengaruhi agresivitas pajak yaitu capital intensity. Capital intensity adalah aktivitas dari perusahaan yang berhubungan dengan investasi melalui aset tetap (Novitasari dan Shelly, 2017). Ayu dan Putu (2017) menyatakan bahwa capital intensity memiliki pengaruh negatif terhadap agresivitas pajak". Berbeda dengan penelitian yang dilakukan Mustika (2017) yang memperoleh hasil bahwa capital intensity tidak memilliki pengaruh pada agresivitas pajak.

Dalam struktur perusahaan, stakeholder memiliki hak untuk memperoleh informasi terkait aktifitas perusahaan yang mempengaruhinya, yang mana menurut Friedman (1962) tujuan utama perusahaan ialah untuk memaksimumkan kemakmuran pemiliknya. Tidak jauh berbeda dengan pendapat Ghazali dan Chariri (2007), teori stakeholder merupakan teori yang tidak hanya mementingkan kepentingan perusahaan itu sendiri, namun harus mementingkan kepentingan stakeholder baik itu pemegang saham, supplier, kreditor, konsumen, pemerintah, dan masyarakat. Adapun cara untuk memperhatikan kepentingan tersebut dengan mentaati peraturan yang dibuat salah satunya yaitu taat membayar pajak tanpa melakukan agresivitas pajak.

Menurut UU Perpajakan Nasional, pajak adalah iuran wajib yang harus dibayarkan oleh rakyat baik pribadi maupun badan kepada Negara yang bersifat memaksa berdasarkan peraturan undang-undang. Adapun sistem perpajakan yang dianut Indonesia yang mencerminkan tanggung jawab atas kewajiban membayar pajak dilakukan dengan sistem self assessment.

Agresivitas pajak merupakan suatu tindakan yang bertujuan untuk menurunkan kewajiban perpajakan perusahaan dengan merekayasa laba melalui perencanaan pajak 
baik menggunakan cara legal (tax avoidance) maupun illegal (tax evasion). Agresivitas pajak yang berada dalam grey area apakah ia menghindari pajak dengan memanfaatkan kelemahan hukum.

Hanafi dan Halim (2009:83) mengartikan profitabilitas sebagai kemampuan perusahaan dalam menghasilkan keuntungan dari pendapatan terkait penjualan, asset dan ekuitas. Dimana perusahaan yang memiliki profitabilitas yang tinggi kerap kali mendapat perhatian di kalangan masyarakat maupun pemerintah, yang berakibat pada tingginya beban pajak. Hal tersebut menjadi salah satu penyebab perusahaan akan menggunakan metode akuntansi yang dapat mengurangi laba sehingga akan mengurangi beban pajak yang harus dibayarkan perusahaan. Peneliti menggunakan rasio Return On Assets (ROA) untuk menghitung profitabilitas.

Suatu perusahaan dalam meningkatkan profitnya dengan didasarkan pada keputusan keuangan yang dinilai melalui capital intensity. Dimana capital intensity mampu mengukur seberapa besar modal yang deperlukan untuk menghasilkan pendapatan. Adapun dana yang dihasilkan bersumber dari perolehan aktiva tetap baik penurunan maupun peningkatan atau dalam kata lain capital intensity menunjukkan besaran asset perusahaan yang diinvestasikan dalam bentuk aktiva tetap. Pengukuran variabel ini penulis menggunakan rasio total asset tetap/total asset x $100 \%$.

\section{Pengembangan Hipotesis}

Menurut (Nugraha dan Meiranto, 2015) perusahaan yang memiliki kemampuan untuk menghasilkan keuntungan yang besar harus siap dengan pajak yang akan dibayarkan. Pendapatan yang diperoleh Perusahaan cenderung berbanding lurus dengan pajak yang dibayarkan (Ardyansah 2014). ETR penulis gunakan sebagai indikator beban pajak Perusahaan. ETR yang rendah akan menyebabkan beban pajak yang dibayar menjadi rendah, sehingga laba Perusahaan tetap tinggi. Maka dari itu perusahaan akan melakukan Agresivitas Pajak demi mengurangi beban pajak tinggi yang harus dibayar sehingga laba yang diperoleh perusahaan tetap tinggi. $\mathrm{H}_{1}$ : Profitabilitas berpengaruh terhadap Agresivitas Pajak.

Penelitian ini menggunakan Intensitas Aset Tetap yang mana pada umumnya akan mengalami penyusutan, karena untuk mengecilkan pajak yang dibayar manajer kerap menggunakan biaya depresiasi. Adapun cara lain untuk mengurangi pajak perusahaan yaitu dengan berinvestasi asset. Perusahaan bukan sengaja menyimpan proporsi aset yang besar untuk menghindari pajak melainkan Perusahaan mungkin menggunakan aset tetap tersebut untuk tujuan operasional Perusahaan (Adisamartha dan Noviari, 2015). $\mathrm{H}_{2}$ : Capital Intensity dapat memoderasi pengaruh antara profitabilitas terhadap Agresivitas Pajak

\section{METODE PENELITIAN}

Populasi dalam penelitian ini adalah perusahaan pertambangan batu bara periode 2014-2018 yang listing di Bursa Efek Indonesia. Pengambilan sample dilakukan dengan metode purposive sampling. Kriteria penentuan sampel dalam penelitian ini adalah sebagai berikut: a) Perusahaan terdaftar (listed) di Bursa Efek Indonesia (BEI), b) Perusahaan yang menyajikan laporan keuangan selama tahun 2014-2018. c) Perusahaan pertambangan batu bara yang menerbitkan laporan keuangan secara berturut-turut di BEI selama 20142018. d) Laporan keuangan perusahaan yang memuat informasi secara lengkap.

Penelitian ini termasuk dalam jenis penelitian statistik deskriptif dengan menggunakan uji hipotesis dan model regresi yaitu analisis regresi linear berganda. Variable independen dalam penelitian ini yaitu profitabilitas dengan menggunakan ROA sebagai proksi untuk mengukur profitabilitas. Capital intensity sebagai variable moderasi yang diukur dengan formula total asset, untuk mengukur faktor memperkuat atau memperlemah terhadap variable dependen yaitu agresivitas pajak.

Metode analisis data yang digunakan yaitu dengan MRA (Moderated Regression Analysis) dengan menggunakan IBM SPSS 25. Model yang digunakan dalam penelitian
Tax aggressiveness,

Profitability and

Capital Intensity

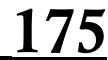


Tax aggressiveness, Profitability and Capital Intensity ini menggunakan persamaan regresi linear berganda yang dapat dinyatakan sebagai berikut:

Keterangan:
$\mathrm{Y}$
$\mathrm{X}_{1}$
$\mathrm{Z}_{1}$
$a$
$\mathrm{~b}_{1}, \mathrm{~b}_{2}$
$\mathcal{E}$

$$
Y=a+b_{1} X_{1}+b_{1} X_{1}^{*} Z_{1}+\varepsilon
$$

$$
\begin{aligned}
& =\text { Agresivitas Pajak } \\
& =\text { Profitabilitas } \\
& =\text { Capital Intensity } \\
& =\text { Konstanta } \\
& =\text { Koefisien regresi variable independen } \\
& =\text { Error }
\end{aligned}
$$

\section{HASIL DAN PEMBAHASAN}

Deskripsi Sampel

Penelitian ini menggunakan data sekunder yang berasal dari perusahaan industry pertambangan batu bara yang terdaftar di Bursa Efek Indonesia. Adapun objek penelitiannya yaitu laporan tahunan perusahaan periode 2014 sampai dengan 2018 dengan jumlah sampel 40.

Analisa Data

\section{Tabel 2}

Hasil Uji Parsial

\begin{tabular}{cccc}
\hline Variable & Coefficient & Probability & Sig. \\
\hline ROA & 0.080354 & 0.0335 & 0.05 \\
\hline CAPINT & 0.083587 & 0.1492 & 0.05 \\
\hline C & 0.907295 & 0.0323 & 0.05 \\
\hline
\end{tabular}

Sumber : data diolah

\section{Pembahasan \\ Pengaruh profitabilitas terhadap agresivitas pajak}

Berdasarkan table 2 diketahui bahwa profitabilitas memiliki nilai koefisien sebesar 0,08 dan nilai probability sebesar 0,1492 lebih kecil dari nilai sig $(0,05)$ sehingga dapat dijelaskan bahwa berpengaruh positif terhadap agresivitas pajak dengan level signifikan $5 \%$. Maka dari itu $\mathrm{H}_{1}$ yang menyatakan Profitabilitas berpengaruh terhadap Agresivitas Pajak diterima.

Dengan demikian hasil diatas sejalan dengan penelitian Prasista dan Setiawan (2016) bahwa profitabilitas berpengaruh terhadap agresivitas pajak. Artinya, perusahaan mencoba untuk mempertahankan laba dengan melakukan agresivitas pajak. Dimana hal tersebut mengakibatkan beban pajak menjadi kecil sehingga menimbulkan laba setelah dikurangi beban pajak tersebut menjadi tinggi, yang artinya kinerja perusahaan tersebut berhasil.

Pengaruh Capital Intensity yang memoderasi profitabilitas terhadap Agresivitas Pajak

Berdasarkan table 2 diketahui bahwa capital intensity memiliki nilai koefisien sebesar 0,08 dan nilai probability sebesar 0,032 lebih kecil dari nilai sig $(0,05)$ sehingga dapat dijelaskan bahwa capital intensity berpengaruh positif memoderasi profitabilitas terhadap agresivitas pajak dengan level signifikan 5\%. Maka dari itu $\mathrm{H}_{2}$ yang menyatakan capital intensity berpengaruh positif memoderasi Profitabilitas terhadap Agresivitas Pajak diterima.

Adapun penelitian I Made, I Putu dan Sukma (2017) memiliki hasil yang sejalan dengan yang uji penulis dimana capital intensity berpengaruh terhadap Agresivitas pajak. Yang artinya perusahaan lebih memilih berinvestasi pada asset, sehingga perusahaan dapat mengurangi beban pajaknya melalui depresiasi aktiva tetap. Dimana tingginya depresiasi aktiva tetap mampu mengurangi laba sebelum pajak, hal ini disebabkan oleh preferensi perpajakan yang terkait dengan investasi asset tetap. Sayangnya hal tersebut membuat ETR perusahaan menjadi rendah sehingga membuat perusahaan semakin agresif terhadap pajak. 


\section{PENUTUP}

Berdasarkan pembahasan mengenai pengaruh profitabilitas terhadap agresivitas pajak dengan capital intensity sebagai variabel moderasi maka dapat ditarik kesimpulan yaitu: Profitabilitas berpengaruh terhadap Agresivitas Pajak dan Capital Intensity berpengaruh dalam memoderasi pengaruh profitabilitas terhadap agresivitas pajak. Saran yang diperuntukkan untuk penelitian selanjutnya, diantaranya: adanya penambahan data perusahaan, peneliti selanjutnya dapat menggunakan data perusahaan selain industri pertambangan, dan menambahkan banyak variabel lain dalam meneliti.

\section{DAFTAR PUSTAKA}

Atami, A. G. (2017). Pengaruh Corporate Governance, Manajemen Laba. dan Captal Intensity Terhadap Agresivitas Pajak. Jom Fekon, 4(1), 2965-2979.

Evianti, D. (2019). Perancangan SOP Divisi Keuangan Dalam Menunjang Sistem Penerimaan dan Pengeluaran Kas PT. Smartelco Solusi Tekhnologi. Jurnal Ilmiah Akuntansi Kesatuan, 7(3), 361-368.

Ferina, V., \& Amrulloh, A. (2020). Analisis Kinerja Keuangan Pada Industri Property dan Real Estate Serta Kontribusinya Terhadap Pendapatan Negara Dari Sektor Pajak. Jurnal Ilmiah Akuntansi Kesatuan, 8(2), 227-236.

Fadillah, D. N., \& Triandi, T. (2019). Analisis Pengakuan, Pengukuran dan Pengungkapan Imbalan Pasca Kerja Berdasarkan PSAK No. 24 (revisi 2013) dan Dampak Perubahannya terhadap Laporan Keuangan Pada Perusahaan Yang Terdaftar Dalam Bursa efek Indonesia. Jurnal Ilmiah Akuntansi Kesatuan, 7(2), 246257.

Firmansyah, I., \& Pramiudi, U. (2020). Analisis Pengendalian Intern Atas Sistem Informasi Penjualan Terhadap Efektivitas Dan Efisiensi Penjualan PT. Enseval Putera Megatrading Tbk. Jurnal Ilmiah Akuntansi Kesatuan, 8(1), 1-8.

Ghozali. (2005). Analisis Multivariate dengan SPSS (UNDIP, ed.). Semarang.

Jatikusuma, M., \& Nurjanah, Y. (2020). Penggunaan Metode Beneish Ratio Index Untuk Mendeteksi Kecurangan Pada Laporan Keuangan. Jurnal Ilmiah Akuntansi Kesatuan, 8(2), 177-186.

Jessica, \& Agus Arianto Toly. (2014). Pengaruh Pengungkapan Program Corporate Social Responsibility. Tax \& Accounting Review, 5(2), 193-203.

Kodey, D. K., Rosita, S. I., \& Sari, E. I. (2020). Pengaruh Hutang dan Modal Kerja terhadap Profitabilitas. Jurnal Ilmiah Akuntansi Kesatuan, 8(2), 127-136.

Makhfudloh, F., Herawati, N., \& Wulandari, A. (2018). Pengaruh Corporate Social Responsibility terhadap Perencanaan Agresivitas Pajak. Jurnal Akuntansi Dan Bisnis, 18(1), 48. https://doi.org/10.20961/jab.v18i1.235

Muanas, M., \& Sufriyanti, F. (2018). Peranan Sistem Aplikasi FASt Terhadap Efektivitas Pengendalian Intern Piutang Dagang (Studi Kasus pada PT KEA Panelindo). Jurnal Ilmiah Akuntansi Kesatuan, 6(1), 53-62.

Mulyana, M., Hakim, D. B., \& Hartoyo, S. (2020). Entrepreneurial Activities And Performance Of Rice Farming In Bojongpicung Sub-District, Cianjur Regency. European Journal of Molecular \& Clinical Medicine, 7(3), 4528-4535.

Nataldy, C., \& Pardede, R. P. (2019). Analisis Perlakuan Akuntansi atas Pendapatan Premi dan beban klaim Sesuai PSAK No. 28 pada PT. Asuransi Astra buana. Jurnal Ilmiah Akuntansi Kesatuan, 7(2), 258-265.

Purba, J. H. V., Ratodi, M., Mulyana, M., Wahyoedi, S., Andriana, R., Shankar, K., \& Nguyen, P. T. (2019). Prediction Model in Medical Science and Health Care. International Journal of Engineering and Advanced Technology, 8, 815-818.

Priscilia, A., \& Agoes, S. (2019). Faktor Yang Mempengaruhi Agresivitas Pajak Perusahaan Manufaktur Yang Terdaftar Di BEI. I(3), 979-987.

Rosalia, R., \& Zulkarnain, P. D. (2020). Pengaruh Akuntabilitas, Potensi Daerah dan Aset Daerah terhadap Transparansi Pemerintah Daerah. Jurnal Ilmiah Akuntansi Kesatuan, 8(2), 167-176.
Tax aggressiveness, Profitability and Capital Intensity 
Tax aggressiveness, Reminda, A. D. (2017). PENGARUH CORPORATE SOCIAL REPONSIBILITY, Profitability and

Capital Intensity PROFITABILITAS , UKURAN PERUSAHAAN DAN CAPITAL INTENSITY TERHADAP AGRESIVITAS PAJAK ( Studi Empiris pada Perusahaan Perbankan yang Terdaftar di BEI Periode Tahun 2013-2015 ). JOM Fekon, Vol. 4(2), 4279-4293. Septiani, S., \& Herawati, H. (2020). Peranan Anggaran Biaya Produksi Sebagai Alat Pengendalian Biaya Produksi Pada PT Yudhistira Ghalia Indonesia-Bogor. Jurnal Ilmiah Akuntansi Kesatuan, 8(2), 207-216.

Susanto, L., Yanti, Y., \& Viriany, V. (2018). Faktor-faktor yang mempengaruhi agresivitas pajak. Jurnal Ekonomi, 23(1), 10-19. https://doi.org/10.24912/je.v23i1.330

Yuliandi, Y. (2019). Analisis Penyebab Pembetulan Spt Ppn Sebagai Pemenuhan Kewajiban Pelaporan Spt Ppn.(Studi Kasus Pt. Pgp). Jurnal Ilmiah Akuntansi Kesatuan, 7(1), 239-245. 